\title{
Maitohappobakteeriympin ja kaliumsorbaatin vaikutus esikuivatun säilöre- hun laatuun ja pötsin käymistyyppiin
}

\author{
Eeva Saarisalo $^{1)}$, Eija Skyttä ${ }^{2)}$ ja Seija Jaakkola ${ }^{1)}$ \\ ${ }^{1)}$ MTT/Eläinravitsemus, 31600 Jokioinen (etunimi.sukunimi@mtt.fi) \\ ${ }^{2)}$ VTT/Biotekniikka, PL 1500,02044VTT (eija.skytta@vtt.fi)
}

\section{Johdanto}

Eri säilöntäaineilla tehtyjen, tuoreiden säilörehujen käymistyypin on todettu vaikuttavan ruuansulatuskanavasta eläimen käyttöön tulevien ravintoaineiden koostumukseen ja sitä kautta tuotantoon ja sen tehokkuuteen (Miettinen 1997, Huhtanen 1998). Esikuivatus sinänsä rajoittaa rehussa tapahtuvaa käymistä, joten säilöntäaineiden vaikutukset syöntiin ja eläimen ravintoaineiden saantiin voivat olla erilaiset esikuivatussa ja tuoreessa rehussa.

Lactobacillus plantarum (VTT E-78076, lyhennettynä E76) maitohappobakteerikannan on todettu tuottavan tehokkaaksi maitohappoa, jolloin rehun $\mathrm{pH}$ laskee nopeasti säilymisen kannalta riittävän alas. Toisaalta E76 on myös selvästi vähentänyt ruohon valkuaisen hajoamista ilman säilöntäainetta tehtyyn rehuun verrattuna (Saarisalo ym 2002b). Ensimmäisessä maatilamittakaavan kokeessa E76 tuotti käymislaadultaan hyvää esikuivattua rehua. Maidontuotannossa rehutypen hyväksikäyttö oli E76rehulla parempi kuin rajoittuneesti käyneellä tai painorehulla (Saarisalo ym 2002a). Tämän perusteella myös esikuivatun rehun käymistyyppi ja valkuaisen hajoamisaste vaikuttavat eläimen ravintoaineiden saantiin ja sitä kautta täydennysrehun tarpe eseen.

E76:1la säilötty rehu on kuitenkin ollut herkkää aerobiselle pilaantumiselle (Saarisalo ym. 2002b). Tässä kokeessa tutkittiin E76 ympin sekä E76:n ja kaliumsorbaatin yhdistelmän vaikutusta säilörehun laatuun. Kaliumsorbaatti (E202) on elintarvikkeissa käytetty lisäaine, joka estää hiivojen ja homeiden kasvua happamassa ympäristössä. Pötsifistelöidyillä lypsylehmillä tutkittiin säilörehujen vaikutusta pötsin käymistyyppiin sekä maidontuotantoon. Kontrolleina olivat painorehu ja muurahaishapolla säilötty, rajoittuneesti käynyt rehu. Samoilla rehuilla on tehty myös maidontuotantokoe (Saarisalo ym. 2003).

\section{Aineisto ja menetelmät}

Esikuivatut säilörehut tehtiin Jokioisten kartanoiden Lintupajun tilalla 15.-17.6.2001 toisen vuoden timotei-nurminatanurmesta. Kasvusto kaadettiin niittomurskaimella ja korjattiin tarkkuussilppurilla 6-16 tunnin esikuivauksen jälkeen. Säilöntäainekäsittelyjä oli neljä: 1) Painorehu (PR), ei säilöntäainetta, 2) ha pporehuun (AIV) lisättiin AIV2000:tta 5,4 1/tn (muurahaishappo 550, ammoniumformaatti 240, propionihappo 50, bentsoehappo 10 ja etyylibentsoaatti $10 \mathrm{~g} / \mathrm{kg}$ ), 3) E76-rehuun lisättiin fermentorikasvatettua ja kylmäkuivattua ymppiä (L. plantarum VTT E-78076), 4) E76S-rehuun lisättiin E76-ympin lisäksi kaliumsorbaattia $300 \mathrm{~g} / \mathrm{t}$. Ymppien annostuksen tavoitteena oli $10^{6} \mathrm{pmy} / \mathrm{g}$. Rehut säilöttiin laakasiiloihin. Raaka-aineessa oli kuiva-ainetta oli $292 \mathrm{~g} / \mathrm{kg}$, raakavalkuaista 139, sokeria 130, neutraalidetergenttikuitua (NDF) 556 sekä D-arvo $714 \mathrm{~g} / \mathrm{kg}$ ka.

Pötsin käymistyyppiä selvitettiin neljällä pötsifistelöidyllä lehmällä tasapainotetun 4 x 4 latinalaisen neliön kokeessa, jossa jakson pituus oli kaksi viikkoa. Väkirehu koostui ohrasta 324,5, kaurasta 324,5, leikkeestä 150, rypsirouheesta 170 sekä kivennäisistä ja suolasta $31 \mathrm{~g} / \mathrm{kg}$. Väkirehussa oli raakavalkuaista 166, tärkkelystä 347 ja NDF:a 209 g/kg ka. Koska lehmät olivat eri tuotosvaiheessa, niistä kahdelle annettiin väkirehua 9 ja kahdelle $11 \mathrm{~kg} / \mathrm{pv}$. Tavoitteena oli väkirehu:säilörehu -suhde 40:60. Väkirehut jaettiin neljässä erässä klo 6:00, 9:00, 18:00 ja 19:30. Säilörehua annettiin vapaasti niin, että jätettä jäi 5$10 \%$ annetusta määrästä.

Säilörehuista määritettiin jaksoittain kuiva-aine (korjattu haihtuvien aineiden osalta), tuhka, typpi tuoreesta, NDF, $\mathrm{pH}$, ammonium-N, pelkistävät sokerit, etanoli, maitohappo, muurahaishappo, VFA:t ja in vitro -sellulaasisulavuus. Väkirehuista analysoitiin jaksoittain kuiva-aine ja kahden jakson yhdistetyistä näytteistä tuhka, raakavalkuainen, raakarasva, raakakuitu, tärkkelys ja NDF. Rehua rvot laskettiin Tuorin ym. (2000) mukaan. Rehujen syönti ja maitotuotos mitattiin päivittäin. Tulosten laskemisessa käytettiin jakson kuuden viimeisen päivän tietoja. Maitonäytteet otettiin jakson lopussa neljältä lypsykerralta ja ne yhdistettiin maitomäärien suhteessa lehmäkohtaisiksi näytteiksi. Maidosta analysoitiin rasva, valkuainen, laktoosi ja somaattiset solut. Maidon urea analysoitiin kahden lypsykerran yhdistetystä näytteestä. Pötsinestettä otettiin jakson 13 päivänä ennen ruokintaa klo 5:30 ja sen jälkeen 1,5 tunnin vä- 
lein 16:30 asti. Näytettä otettiin kerralla $100-150$ ml. Suodatuksen jälkeen sitä mitattiin välittömästi pH ja pipetoitiin näytteet VFA- ja ammoniakkimäärityksiin, nämä pakastettiin analyyseja varten.

Syönti- ja maidontuotantodata sekä pötsifermentaatioparametrien aikojen keskiarvot testattiin varianssianalyysillä SAS GLM proseduurilla mallilla, jossa oli eläin, jakso ja ruokinta. Ruokinnan neliösumma jaettiin edelleen ortogonaalisiin kontrasteihin: 1) PR vs. säilöntäaineet, 2) AIV vs. ympit, 3) E76 $v s$. E76S. Pötsifermentaatiodata testattiin myös MIXED-proseduurilla, jossa mallissa oli myös näytteenottoaika sekä yhdysvaikutukset aika*jakso ja aika*ruokinta.

\section{Tulokset ja niiden tarkastelu}

Säilörehujen D-arvo oli keskimäärin $703 \mathrm{~g} / \mathrm{kg}$ ka eli rehujen sulavuus oli hyvä (Taulukko 1). Käymisla adultaan säilörehut täyttivät hyvän rehun laatuvaatimukset lukuunottamatta painorehua, jossa oli ammoniumtyppeä 83, kun hyvän rehun raja on $80 \mathrm{~g} / \mathrm{kg} \mathrm{N}$. Rehujen käymistyypissä oli kuitenkin selvät erot. Ymppirehujen $\mathrm{pH}$ oli noin 0,3 yksikköä pienempi kuin paino- ja happorehun. Painorehussa oli vähiten sokereita jäljellä (27,4 g/kgka), mutta käymisessä oli muodostunut muita rehuja enemmän etanolia, etikkahappoa ja voihappoa. AIV-rehussa käyminen oli rajoittuneempaa, sillä siinä oli eniten sokereita jäljellä (94,2 g/kg ka). E76- ja E76S-rehuissa käyminen oli varsin maitohappovaltaista (91\% käymishapoista) ja sokeria oli jäljellä 50,9 ja 54,6 g/kg ka. E76- ja E76S-rehujen samanlaisen käymislaadun perusteella kaliumsorbaatti ei vaikuttanut maitohappobakteerien toimintaan. Myös pienen ammoniumtypen osuuden $(30,5 \mathrm{ja} 28,5 \mathrm{~g} / \mathrm{kg} \mathrm{N})$ perusteella molemmissa ymppirehuissa maitohappokäyminen on laskenut $\mathrm{pH}: \mathrm{n}$ nopeasti.

Keskimäärin lehmät söivät säilörehua $12,2 \mathrm{~kg}$ ka/pv eikä rehujen syönneissä ollut eroja (Taulukko 2). Energiakorjattu maitotuotos (EKM) oli painorehulla muita ruokintoja pienempi $(27,4$ vs. 28,3), mutta ero ei ollut tilastollisesti merkitsevä $(\mathrm{P}=0,135)$. AIV-rehulla maidon rasva-, valkuais- ja laktoosipitoisuudet olivat ymppirehuja suurempia, mutta nämäkään erot eivät olleet tilastollisesti merkitseviä. Sen sijaan maidon ureapitoisuus oli merkitsevästi pienempi AIV-rehulla kuin ymppirehuilla $(20,2$ vs. 23,4, P>0,01). Rasvatuotos oli painorehulla keskimäärin $59 \mathrm{~g}$ pienempi kuin muilla rehuilla $(\mathrm{P}<0,05)$. Valkuais- ja laktoosituotokset olivat ymppirehuilla keskimäärin 907 ja 1345 g, kun AIV-rehulla ne olivat 875 ja 1294 g, mutta erot eivät olleet tilastollisesti merkitseviä. Samoilla rehuilla tehdyssä tuotantokokeessa lehmät söivät AIV-rehua 0,7 kg ka/pv enemmän kuin ymppirehuja (Saarisalo ym. 2003). Tästä huolimatta maidon-

Taulukko 1. Säilörehujen koostumus ja käymislaatu.

\begin{tabular}{lcccc}
\hline \hline & \multicolumn{4}{c}{ Säilörehu } \\
\cline { 2 - 5 } & PR & AIV & E76 & E76S \\
\hline Kuiva-aine, g/kg & 280 & 301 & 280 & 261 \\
$\mathrm{pH}$ & 4,20 & 4,17 & 3,92 & 3,90 \\
Tuhka, g/kg ka & 80,3 & 79,9 & 76,3 & 79,5 \\
Raakavalkuainen, g/kg ka & 137 & $143 / 135^{\text {a }}$ & 133 & 135 \\
Sokeri, g/kg ka & 27,4 & 94,2 & 50,9 & 54,6 \\
Maitohappo, g/kg ka & 82,4 & 51,0 & 102,6 & 108,3 \\
Etanoli, g/kg ka & 11,03 & 2,20 & 4,28 & 5,13 \\
IVOAS, g/kg ka & 754 & 763 & 760 & 761 \\
D-arvo, g/kg ka & 697 & 706 & 704 & 703 \\
Etikkahappo, g/kg ka & 17,47 & 13,51 & 8,53 & 8,71 \\
Propionihappo, g/kg ka & 0,39 & 0,75 & 0,61 & 0,35 \\
Voihappo, g/kg ka & 1,00 & 0,45 & 0,74 & 0,82 \\
VFA yhteensä, g/kg ka & 19,8 & 14,9 & 10,5 & 10,2 \\
Maitohappo/Käymishapot & 0,81 & 0,77 & 0,91 & 0,91 \\
Maitohappo/Etikkahappo & 4,81 & 3,81 & 12,5 & 12,7 \\
NH ${ }_{3}$-N, g/kg N & 83,0 & $75,3 / 31,3^{\text {a }}$ & 30,5 & 28,5 \\
Syönti-indeksi & 97 & $101 / 106^{\infty}$ & 101 & 101 \\
\hline Saiörehut: PR = Painorehu & & & & \\
\hline
\end{tabular}

Säilörehut: PR = Painorehu, AIV = AIV2000, E76 = Lactobacillus plantarum (VTT E-78076)

$\mathrm{E} 76 \mathrm{~S}=\mathrm{E} 76+300 \mathrm{~g} / \mathrm{t}$ kaliumsorbaattia.

IVOAS = Orgaanisen aineen in vitro sellulaasi sulavuus

${ }^{\circledR}$ Analysoitu / analysoitu - säilöntäaineessa lisätty 
Taulukko 2. Rehujen syönti, maidontuotanto ja maidon koostumus sekä pötsifermentaatio.

\begin{tabular}{|c|c|c|c|c|c|c|c|c|}
\hline & \multicolumn{4}{|c|}{ Säilörehu } & \multirow[b]{2}{*}{ SEM } & \multicolumn{3}{|c|}{ Tilastolliset merkitsevyydet } \\
\hline & PR & AIV & E76 & E76S & & $\begin{array}{l}\text { PR vs. } \\
\text { muut }\end{array}$ & $\begin{array}{l}\text { AIV vs. } \\
\text { Ympit }\end{array}$ & $\begin{array}{c}\text { E76 vs. } \\
\text { E76S }\end{array}$ \\
\hline \multicolumn{9}{|l|}{ Syönnit, kg ka/pv } \\
\hline Säilörehu & 12,3 & 12,1 & 12,2 & 12,2 & 0,52 & & & \\
\hline Väkirehu & 8,4 & 8,4 & 8,4 & 8,3 & 0,07 & & & \\
\hline Yhteensä & 20,7 & 20,5 & 20,6 & 20,5 & 0,51 & & & \\
\hline Maito, $\mathrm{kg} / \mathrm{pv}$ & 27,6 & 26,9 & 27,9 & 28,2 & 0,65 & & & \\
\hline $\mathrm{EKM}, \mathrm{kg} / \mathrm{pv}$ & 27,4 & 28,0 & 28,1 & 28,8 & 0,42 & & & \\
\hline \multicolumn{9}{|l|}{ Pitoisuudet, $\mathrm{g} / \mathrm{kg}$} \\
\hline Rasva & 41,9 & 44,6 & 42,2 & 43,3 & 0,87 & & & \\
\hline Valkuainen & 32,7 & 33,1 & 32,6 & 33,0 & 0,25 & & & \\
\hline Laktoosi & 47,7 & 48,0 & 47,8 & 47,8 & 0,11 & & & \\
\hline Urea $\mathrm{mg} / 100 \mathrm{ml}$ & 22,4 & 20,2 & 22,6 & 24,2 & 0,53 & & $* *$ & o \\
\hline \multicolumn{9}{|l|}{ Tuotokset, g/pv } \\
\hline Rasva & 1105 & 1166 & 1141 & 1186 & 16,3 & $*$ & & \\
\hline Valkuainen & 884 & 875 & 897 & 916 & 18,7 & & & \\
\hline Laktoosi & 1323 & 1294 & 1339 & 1351 & 30,0 & & & \\
\hline \multicolumn{9}{|l|}{ Pötsifermentaatio } \\
\hline $\mathrm{pH}$ & 6,31 & 6,34 & 6,25 & 6,34 & 0,05 & & & \\
\hline $\mathrm{NH}_{3}, \mathrm{mmol} / \mathrm{l}$ & 5,91 & 7,12 & 7,98 & 8,03 & 0,72 & o & & \\
\hline VFA, mmol/1 & 107,2 & 104,2 & 107,0 & 107,3 & 1,32 & & & \\
\hline \multicolumn{9}{|c|}{ Osuus VFAsta mmol/mol } \\
\hline Etikkahappo & 626 & 645 & 629 & 624 & 3,1 & & $* *$ & \\
\hline Propionihappo & 197 & 180 & 201 & 208 & 3,9 & & $* *$ & \\
\hline Voihappo & 134 & 136 & 131 & 131 & 3,7 & & & \\
\hline
\end{tabular}

Kontrastit: PR vs. muut = painorehu vs. säilöntäaineet, AIV vs. Ympit = AIV2000 vs. E76 ja E76S.

Tilastolliset merkitsevyydet: *** $\mathrm{P}<0,001, * * \mathrm{P}<0,01 * \mathrm{P}<0,05$, o $\mathrm{P}<0,10$.

tai EKM-tuotannossa ei ollut eroa. Maidon rasva- ja valkuaispitoisuus oli tuotantokokeessa AIV-rehua saaneilla lehmillä suurempi $(\mathrm{P}<0,10)$ samoin kuin fistelilehmillä. Säilörehun syönnin on todettu vähenevän erityisesti virhekäymisen (runsas valkuaisen hajoaminen ja sekundäärinen käyminen) seurauksena (Huhtanen 1998). Erot eri säilöntäaineilla tehtyjen esikuivattujen rehujen syönnissä ovat pienemmät kuin esikuivaamattomassa rehussa, koska käymistä ja näin ollen myös virhekäymistä tapahtuu vähemmän.

Pötsin pH oli keskimäärin 6,31 eikä ruokintojen välillä ollut tilastollisesti merkitseviä eroja, vaikka säilörehujen $\mathrm{pH}$ :ssa oli selvät erot. Tämä osoittaa, että pötsissä syljen puskurikapasiteetti riitti tasaamaan erot rehujen happamuudessa. Pötsifermentaatioparametreista aika*ruokinta-yhdysvaikutus oli merkitsevä vain pötsin voihapon osuudessa. Se vaihteli hyvin vähän ymppiruokinnoilla, mutta oli paino- ja AIV-rehulla pienempi ennen ruokintaa, mutta nousi heti ruokinnan jälkeen ymppiruokintojen pitoisuutta suuremmaksi.

Pötsin ammoniakkipitoisuus oli painorehulla muita rehuja pienempi $(5,91 \mathrm{vs} 7,71 \mathrm{mmol} / \mathrm{l}$, $\mathrm{P}=0,07)$, vaikka painorehussa ammoniumtypen osuus oli suurin. Pötsin ammoniakkipitoisuuteen vaikuttaa kuitenkin rehun raakavalkuaispitoisuuden ja valkuaisen laadun lisäksi se miten tehokkaasti ammoniun-N käytetään mikrobivalkuaissynteesiin. AIV-rehulla pötsin VFA-pitoisuus oli 104, kun se muilla ruokinnoilla oli $107 \mathrm{mmol} / \mathrm{l}$ (AIV vs. ympit, $\mathrm{P}=0,12$ ). Ymppirehuilla etikkahapon osuus pötsin VFA:sta oli $627 \mathrm{kun}$ se AIV-rehulla oli $645 \mathrm{mmol} / \mathrm{mol}$ VFA $(\mathrm{P}<0,01)$ ja vastaavasti propionihapon osuus oli ymppirehuilla suurempi, 205 vs. $180 \mathrm{mmol} / \mathrm{mol}$ VFA, kuin AIV-rehulla $(\mathrm{P}<0,01)$ (kuva 1). Tämä johtunee siitä, että rehun maitohappo muutetaan pötsissä pääasiassa propionihapoksi (Jaakkola 1992). Pötsistä imeytyvät etikka- ja voihappo käytetään maitorasvan synteesiin. Kokeen tuloksissa tämä näkyy siinä, että AIV-rehulla ruokittujen lehmien maidon rasvapitoisuus oli suurempi. Propionihappo puolestaan on glukoosin ja maidon laktoosin lähde. Jos propionihappoa ei muodostu riittävästi, eläin joutuu käyttämään aminohappoja glukoosin muodostukseen (Huhtanen 1998). Ymppirehujen etuna on runsas maitohappokäyminen, joka on tuotantokokeissa näkynyt tehokkaana valkuaisen hy- 
väksikäyttönä. Toisaalta rehun käymisen rajoittamisen on todettu lisäävän mikrobivalkuaissynteesiä pötsissä. Tässä kokeessa sitä ei mitattu.

\section{Johtopäätökset}

Ilman säilöntäainetta tehdyn rehun käymislaatu ei ollut yhtä hyvä kuin AIV2000:1la tai ympeillä säilötyssä rehussa. Ymppirehujen käymislaadun perusteella kaliumsorbaatti (300 g/tn) ei vaikuttanut maitohappobakteerien toimintaan.

Erot pötsifermentaatiossa selittävät maidon eri komponenttien suhteellisia tuotoseroja ja tuotantokokeissa havaittuja eroja rehun hyväksikäytössä. Ymppirehun etuna on maitohappokäyminen, joka lisää propionihapon tuotantoa pötsissä ja siten eläimen verensokerin saantia.

Pötsin etikkahappo, mmol/mol VFA

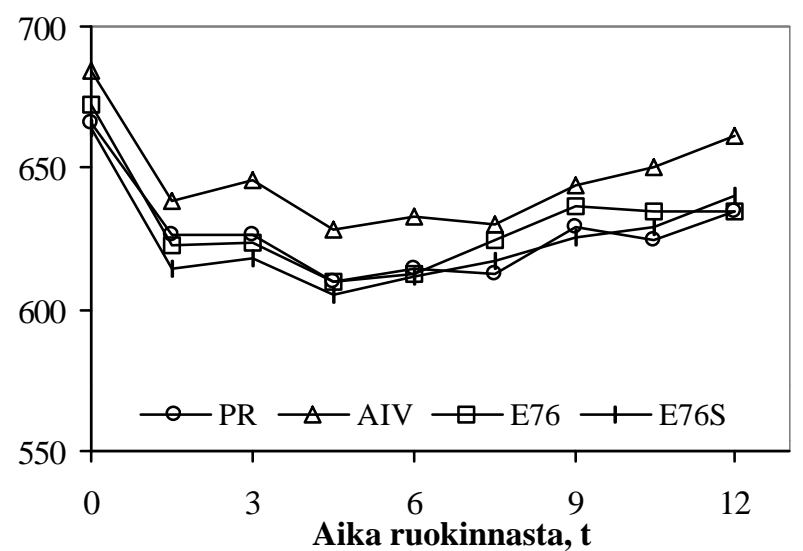

Pötsin propionihappo, mmol/mol VFA

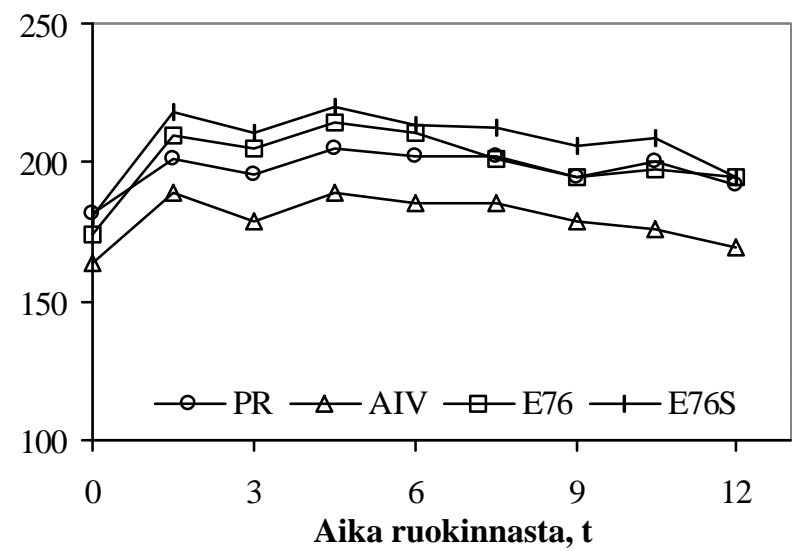

Kuva 1. Säilörehujen vaikutus pötsin etikka- ja propionihapon osuuksiin haihtuvista rasvahapoista.

\section{Kirjallisuus}

Huhtanen, P. 1998. Supply of nutrients and productive responses in dairy cows given diets based on restrictively fermented silage. Agric. Food Sci. Finland 7: 219-250.

Jaakkola, S. 1992. Silage fermentation in relation to the feeding value with special reference to enzyme-treated grass silage. Academic dissertation, Helsinki.

Miettinen, H. 1997. Effects of nutrient supply, especially volatile fatty acids, on blood metabolites, mammary nutrient metabolism and milk production in dairy cows. Academic dissertation, Yliopistopaino, Helsinki.

Saarisalo, E., Jaakkola, S., Skyttä, E. \& Huhtanen, P. 2002a. Maitohappobakteeriymppien vaikutus esikuivattujen säilörehujen laatuun ja lypsylehmien maidontuotantoon. In: toim. Marketta Rinne. Maataloustieteen Päivät 2002 : Kotieläintiede, 9.-10.1.2002 Viikki, Helsinki. Maaseutukeskusten Liiton julkaisuja 977: p. 71-74.

Saarisalo, E., Jaakkola, S., Jalava, T., Skyttä, E. \& Haikara, A. 2002b. Biologiset säilöntävalmisteet nurmirehun säilönnässä. In: toim. Eeva Saarisalo, Mari Topi-Hulmi. Rehuvaihtoehtoja nautakarjatiloille. Seminaari Jokioisilla 29.4.2002. Suomen Nurmiyhdistyksen julkaisu 18: p. 71-79.

Saarisalo, E., Jaakkola, S., Vaari, A. \& Skyttä, E 2003. Effect of protein supplementation of wilted silages varying in fermentation quality on milk production. In: Oiva Niemeläinen and Mari Topi-Hulmi (eds.). Proceedings of the NJF's 22nd congress 'Nordic Agriculture in Global Perspective', July 1-4, 2003, Turku, Finland. Jokioinen: MTT Agrifood Research Finland, NJF. [p. 22].

http://portal.mtt.fi/pls/portal30/docs/FOLDER/AGRONET/YHTEISET HANKKEET/NJF/NJF2003/2.PDF

Tuori, M., Kaustell, K., Valaja, J., Aimonen, E., Saarisalo, E. \& Huhtanen, P. 2000. Rehutaulukot ja ruokintasuositukset. Helsinki. 88 p. 